\title{
Incidence and types of acute viral hepatitis in Newcastle upon Tyne
}

\author{
H.S.R. Hosker, D.C. Lindsay, F. Game, A.A. Codd, G. Dale \\ and C.O. Record
}

Gastroenterology Unit, Royal Victoria Infirmary, Newcastle upon Tyne NE1 4LP, and Departments of Clinical Biochemistry and Virology, Newcastle General Hospital, Westgate Road, Newcastle upon Tyne NE4 $6 B E, U K$.

\begin{abstract}
Summary: The incidence and types of viral hepatitis in the city of Newcastle upon Tyne have been studied by serological analysis of (a) all blood samples sent to the virological laboratory for hepatitis testing and (b) all blood samples sent by general practitioners to the biochemical laboratory for liver function testing. The annual detection rate of acute viral hepatitis was found to be 31.5 cases/100,000 population, of which 9.1 were hepatitis $B$. Only three sporadic cases of non-A non-B hepatitis were identified. The incidence of hepatitis is at least four-fold greater than suggested by notification rates and may be substantially higher as general practitioners rarely requested laboratory confirmation of household contacts of index cases.
\end{abstract}

\section{Introduction}

There have been few studies using modern serological techniques to determine the frequency of viral hepatitis in the community. ${ }^{1,2}$ Notification rates for infective jaundice in the UK have declined since 1982 , with only 7.7 notified cases per 100,000 population in $1985 .^{3}$ There is little evidence for seasonal trends based on weekly notification rates.

We studied the detection rate of viral hepatitis in Newcastle upon Tyne from 1st February to 31st July 1987 using blood samples sent by general practitioners (GPs) and hospital doctors.

\section{Patients and methods}

All blood samples sent by GPs for virological and biochemical analysis at Newcastle General Hospital were included in the study. All blood samples sent for liver function testing alone and found to have aspartate aminotransferase (AST) values of $100 \mathrm{IU} / 1$ or greater (normal<37 IU/l) were identified, and plasma retrieved for serological analysis. In the latter cases, GPs were sent a questionnaire regarding the patient's illness and other relevant factors. Hospital notes were examined where available.

Correspondence: C.O. Record, D.Phil., F.R.C.P., Royal Victoria Infirmary, Newcastle upon Tyne NE1 4LP, UK. Accepted: 16 June 1988
Patients with positive specific IgM antibody hepatitis A, Epstein-Barr virus (EBV) cytomegalovirus (CMV) were considered to have acute infection due to these viruses. Acute hepatitis B was diagnosed in patients with hepatitis B surface antigen positivity only if there was subsequent elimination of surface antigen with development of surface, E or core antibodies. Patients with an appropriate history but with negative serology and no other identifiable cause for a raised AST value were classified as suffering from acute non-A non-B hepatitis.

\section{Results}

The total number of serologically proven cases of hepatitis over the study period was 45 ( 32 hepatitis A, 13 hepatitis B). Sixty-one samples with an AST value of $100 \mathrm{IU} / 1$ or greater were obtained over the same 6-month period, 58 of whom returned questionnaires. Information was obtained from hospital notes in two further patients. A non-viral cause of hepatic dysfunction was established in 38 cases (Table I). Serology confirmed a diagnosis of acute hepatitis in 20 of 23 cases with an elevated AST and appropriate history (Table I). The remaining 3 patients were classified as having non-A non-B hepatitis. In four of the cases the elevated AST was

(C) The Fellowship of Postgraduate Medicine, 1988 
Table I Causes of aspartate aminotransferase $>100 \mathrm{IU} / 1$

\begin{tabular}{|c|c|c|}
\hline Diagnosis & $\begin{array}{c}\text { Number of } \\
\text { patients }\end{array}$ & $\begin{array}{c}\text { Mean age }(y) \\
(\text { and range })\end{array}$ \\
\hline \multicolumn{3}{|l|}{$\begin{array}{l}\text { (A) Viral causes } \\
\text { (appropriate history } \\
\text { and serology) }\end{array}$} \\
\hline Hepatitis A virus & 12 & $17 \quad(5-41)$ \\
\hline Epstein Barr virus & 4 & $29(18-45)$ \\
\hline Hepatitis $\mathbf{B}$ virus & 4 & $26(20-34)$ \\
\hline Non-A Non-B & 3 & $28(17-39)$ \\
\hline Total & 23 & $22 \quad(5-45)$ \\
\hline \multicolumn{3}{|l|}{$\begin{array}{l}\text { (B) Non-viral causes } \\
\text { (inappropriate history and } \\
\text { negative serology) }\end{array}$} \\
\hline Alcohol abuse & 14 & $49(32-74)$ \\
\hline Gallstones & 5 & $63(47-79)$ \\
\hline Malignancy & 4 & $72(63-84)$ \\
\hline \multicolumn{3}{|l|}{ Cardiac failure/ } \\
\hline myocardial infarction & 4 & $69(56-89)$ \\
\hline Non-alcoholic cirrhosis & 2 & $73(65-82)$ \\
\hline Other & 5 & $65(40-80)$ \\
\hline \multicolumn{3}{|c|}{$\begin{array}{l}\text { Lymphoma(1), uraemia(1), empyema(1) } \\
\text { sclerosing cholangitis(1), chronic hepatitis(1). }\end{array}$} \\
\hline No diagnosis & 4 & $60(50-73)$ \\
\hline Total & 38 & $60(32-89)$ \\
\hline
\end{tabular}

due to EB virus. There were no patients with positive CMV serology, or with positive serology for more than one virus.

Of those returning the questionnaire, 10 out of 12 patients with hepatitis $\mathrm{A}$ had an identifiable contact (10 came from the same postal area), and a risk factor was present in all 4 patients with acute hepatitis B ( 2 sexual contact, 1 intravenous drug abuse, 1 travel to Far East). All patients with viral hepatitis were aged less than 50 years and this diagnosis was the cause of hepatic dysfunction in $91 \%$ of the patients aged less than 40 years. Mean age of the viral group (22.2 years) differed signifi-

\section{References}

1. Stewart, J.S., Farrow, L.J., Clifford, R.E. et al. A three year survey of viral hepatitis in west London. $Q \mathrm{~J} \mathrm{Med}$ 1978, 187: 365-384.

2. Bamber, M., Thomas, H.C., Bannister, B. \& Sherlock, S. Acute type A, B and non A, non B hepatitis in a hospital population in London: clinical and epidemiological features. Gut 1983, 24: :561-564.

3. Office of Population Censuses and Surveys Monitor. Infectious Diseases section, June quarter 1986. Published September 1987, Government Statistical Service. cantly from that of the non-viral group (59.8 years, $P<0.001)$.

\section{Discussion}

The biochemistry laboratory at Newcastle General Hospital handles all general practitioner laboratory requests for a population of 240,000 . This community based study suggests an annual detection rate of viral hepatitis in Newcastle upon Tyne (population $285,000)$ of 31.5 cases per 100,000 population. Stewart et al. ${ }^{1}$ reported an overall incidence of 24 cases per 100,000 in a community survey of hepatitis in three London Boroughs but hepatitis A was not serologically confirmed and some EB virus cases may have been included. The hepatitis B infection rate of 9.1 per 100,000 is approximately twice that reported by Polakoff ${ }^{4}$ in her analysis of UK laboratory reports from 1980 to 1984. AST testing and subsequent viral serology did not prove particularly valuable for the diagnosis of hepatitis $A$ and $B$ as only 10 additional cases were identified in this way $(9 \mathrm{~A}, 1 \mathrm{~B})$. It did however permit the recognition of three sporadic cases of non-A non-B hepatitis, the proportion of this form of hepatitis in the community $(6 \%)$ being somewhat less than in hospital populations $\left(13 \%{ }^{2}\right)$.

Studies from Australia ${ }^{5}$ suggest that $67 \%$ of child and $31 \%$ of adult household contacts of hepatitis A cases show seroconversion, but only about a quarter of seroconverting contacts of hepatitis A and B develop overt disease. The incidence of hepatitis, particularly hepatitis $A$, in the community is therefore likely to be much higher than suggested by this study as GPs only infrequently request laboratory confirmation of household contacts of index cases. The incidence of hepatitis is at least four-fold greater than suggested by notification rates.

4. Polakoff, S. Acute viral hepatitis B: laboratory reports 1980-4. Br Med J 1986, 293: 37-38.

5. Broughton, C.R., Hawkes, R.A., Schroeter, D.R. et al. Viral hepatitis: a four year hospital and general practice study in Sydney. 2. Transmission of viral hepatitis among residential contacts in Sydney. Med $J$ Aust 1982, 1: 174-178. 